\title{
Relationship between the actions of atrial natriuretic peptide (ANP), guanylin and uroguanylin on the isolated kidney
}

M.S. Santos-Neto ${ }^{1}$, A.F. Carvalho ${ }^{1}$, L.R. Forte ${ }^{2}$ and M.C. Fonteles ${ }^{1}$
1Divisão de Farmacologia Renal e Metabólica, Unidade de Pesquisas Clínicas, Faculdade de Medicina, Universidade Federal do Ceará, Fortaleza, CE, Brasil ${ }^{2}$ The Truman V.A. M edical Center and Department of Pharmacology, School of Medicine, Missouri University, Columbia, MO, USA

\section{Correspondence \\ M.C. Fonteles \\ Av. José Bastos, 3390, s/90 \\ Campus do Porangabussu \\ 60436-160 Fortaleza, CE \\ Brasil \\ Fax: +55-85-281-5212 \\ E-mail: upc@lia.ufc.br}

Presented at the XIII Annual Meeting of the Federação de Sociedades de Biologia Experimental, Caxambu, MG, Brasil, August 26-29, 1998.

Research supported by CNPq, FINEP and FUNCAP.

Received April 14, 1998 Accepted February 24, 1999

\section{Abstract}

Guanylin and uroguanylin are peptides that bind to and activate guanylate cyclase $\mathrm{C}$ and control salt and water transport in many epithelia in vertebrates, mimicking the action of several heat-stable bacteria enterotoxins. In the kidney, both of them have well-documented natriuretic and kaliuretic effects. Since atrial natriuretic peptide (ANP) also has a natriuretic effect mediated by cGMP, experiments were designed in the isolated perfused rat kidney to identify possible synergisms between ANP, guanylin and uroguanylin. Inulin was added to the perfusate and glomerular filtration rate (GFR) was determined at 10-min intervals. Sodium was also determined. Electrolyte dynamics were measured by the clearance formula. Guanylin $(0.5$ $\mu \mathrm{g} / \mathrm{ml}, \mathrm{N}=12)$ or uroguanylin $(0.5 \mu \mathrm{g} / \mathrm{ml}, \mathrm{N}=9)$ was added to the system after $30 \mathrm{~min}$ of perfusion with ANP $(0.1 \mathrm{ng} / \mathrm{ml})$. The data were compared at 30 -min intervals to a control $(\mathrm{N}=12)$ perfused with modified Krebs-Hanseleit solution and to experiments using guanylin and uroguanylin at the same dose $(0.5 \mu \mathrm{g} / \mathrm{ml})$. After previous introduction of ANP in the system, guanylin promoted a reduction in fractional sodium transport $\left(\% \mathrm{TNa}^{+}, \mathrm{P}<0.05\right)$ (from $78.46 \pm 0.86$ to $64.62 \pm 1.92$, $120 \mathrm{~min}$ ). In contrast, ANP blocked uroguanylin-induced increase in urine flow (from $0.21 \pm 0.01$ to $0.15 \pm 0.007 \mathrm{ml} \mathrm{g}^{-1} \mathrm{~min}^{-1}, 120 \mathrm{~min}$, $\mathrm{P}<0.05$ ) and the reduction in fractional sodium transport (from 72.04 \pm 0.86 to $85.19 \pm 1.48, \% \mathrm{TNa}^{+}$, at $120 \mathrm{~min}$ of perfusion, $\mathrm{P}<0.05$ ). Thus, the synergism between ANP + guanylin and the antagonism between ANP + uroguanylin indicate the existence of different subtypes of receptors mediating the renal actions of guanylins.
Key words
- ANP
- Guanylin
- Uroguanylin
- Kidney
- Natriuresis
- cGMP

Guanylin was the first member of a new family of endogenous peptides which are both structurally and functionally similar to some heat-stable bacterial enterotoxins, especially STa which belongs to the Escheri- chia coli superfamily of heat-stable toxins. Guanylin cDNAs are found in many tissues including intestine, kidney, uterus/oviduct, trachea, brain and adrenal medulla (1). Guanylin activates guanylate cyclase C (GC- 
C) and causes chloride secretion in the T84 colon cancer cell line (2).

Uroguanylin is another analog of STa that was first isolated from rat urine and increases the levels of cGMP in T84 cells and also causes chloride secretion in enterocytes via cystic fibrosis conductance membrane regulator $(3,4)$. Uroguanylin is expressed in the heart, kidney and intestine (5). STa is more potent than uroguanylin, which in turn is more potent than guanylin in the induction of cGMP accumulation in T84 cells (5). Uroguanylin may have a pivotal

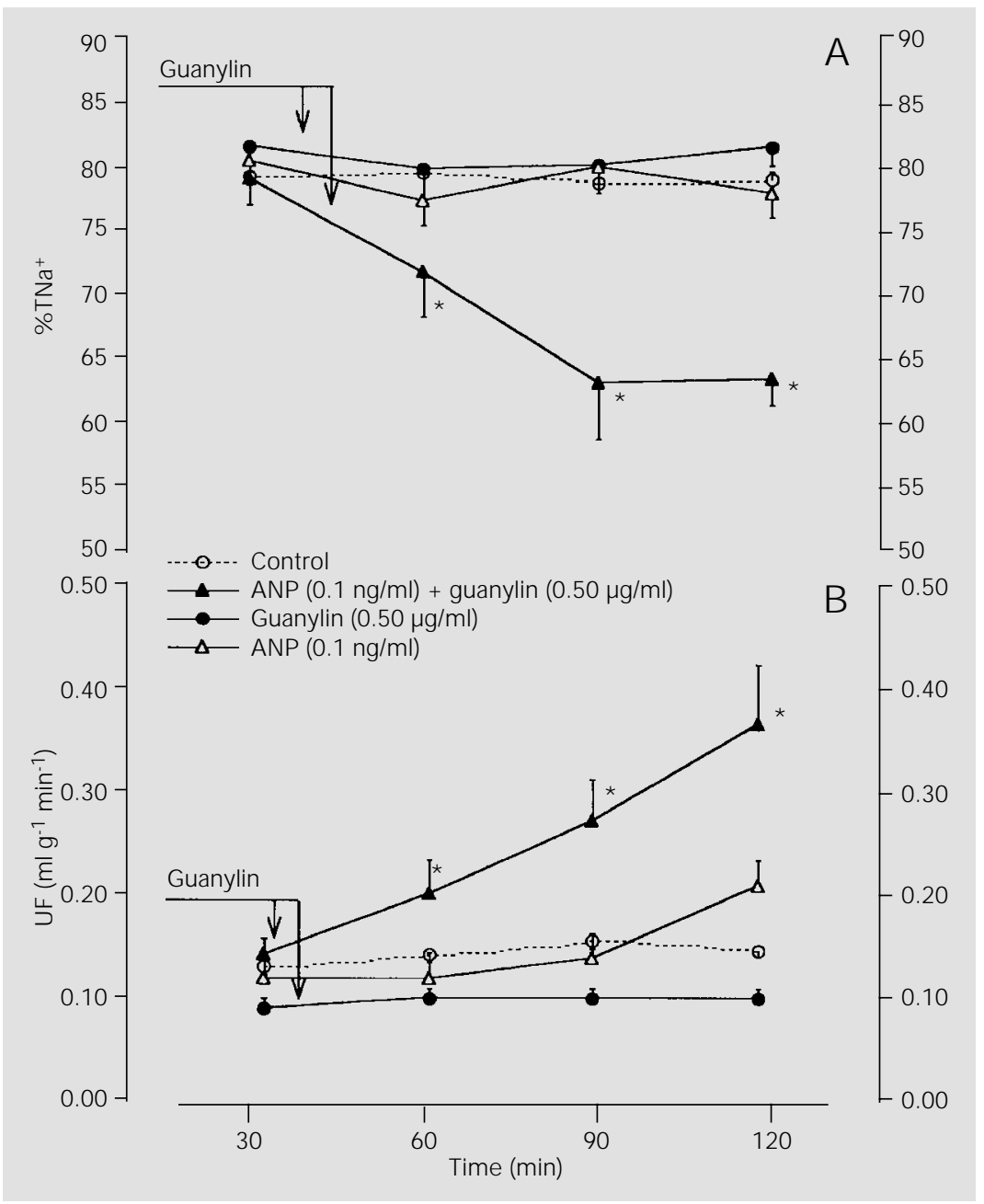

Figure 1 - Diuresis (panel A) and natriuresis (panel B) promoted by guanylin in atrial natriuretic peptide (ANP)-pretreated kidneys. Note that at 60, 90 and 120 min after ANP perfusion, guanylin increased urine flow (UF) and decreased fractional sodium transport $\left(\% \mathrm{TNa}^{+}\right.$). Data are reported as means $\pm \mathrm{SEM} ; \mathrm{N} \geq 9 ; * \mathrm{P}<0.05$ compared to control (ANOVA and Fisher test). role in a novel endocrine axis involving the gut, the heart and the kidney. The intestine may be able to detect the amount of salt ingested and match this load to the excretion of salt by the kidney $(4,6)$.

Both guanylin and uroguanylin have kaliuretic and natriuretic effects in the isolated kidney, similar to those observed for STa $(6,7)$. The actions of cGMP in the kidney were previously demonstrated by Lima and coworkers (7). Also in the kidney uroguanylin has been shown to be more potent than guanylin. Previous work from this laboratory demonstrated that lysilguanylin is also natriuretic (8).

Atrial natriuretic peptide (ANP) is a 28amino acid peptide with well-known effects in the regulation of salt and water excretion in the kidney. It also plays a role in the regulation of arterial blood pressure in a saltsensitive fashion, interacting with other hormonal systems such as the renin-angiotensinaldosterone system $(9,10)$. ANP binds to and activates guanylate-cyclase $\mathrm{A}$ in the kidney (11).

Since the actions of guanylins and ANP are mediated by cGMP, and the three peptides share many similar functions in the kidney, experiments were designed to determine a possible synergism between guanylins and ANP in the isolated rat kidney.

Wistar rats weighing 250-300 $\mathrm{g}$ with free access to water were fasted for $24 \mathrm{~h}$ and anesthetized with sodium pentobarbital (50 $\mathrm{mg} / \mathrm{kg}$, ip $)$. The right kidney was perfused with a modified Krebs-Hanseleit solution as control (Cont, $\mathrm{N}=12$ ), according to the technique previously described by Fonteles et al. (12). At 10-min intervals samples of both urine and perfusate were obtained and analyzed for inulin by the method previously described by Wasler (13) and modified by Fonteles (12) and electrolytes were determined by flame photometry. Glomerular filtration rate (GFR), fractional tubular transport of sodium $\left(\% \mathrm{TNa}^{+}\right)$, as well as urine flow (UF), osmotic clearance (Cosm) and 
perfusion pressure were also determined at 10-min intervals, using the clearance method as previously described (14). A sylastic oxigenator was placed in the perfusion line for oxygenation of the perfusates $\left(\mathrm{pO}_{2}=\right.$ $450-500 \mathrm{mmHg}$ ) according to Fonteles et al. (12).

Rat guanylin and opossum uroguanylin were synthesized by a solid-phase method (15). The structure and purity of the peptides were confirmed by amino acid analysis, electrospray mass spectrometry and gas phase sequence analysis. The ANP used in these experiments was purchased from Sigma Chemical Co., St. Louis, MO, USA.

After 30 min of perfusion with ANP $(0.1$ $\mathrm{ng} / \mathrm{ml})$, guanylin $(0.5 \mu \mathrm{g} / \mathrm{ml}, \mathrm{N}=12)$ or uroguanylin $(0.5 \mu \mathrm{g} / \mathrm{ml}, \mathrm{N}=9)$ was added to the system and the data (reported as means \pm SEM) were obtained by comparing the results at 30-min intervals to the internal control and to experiments in which the kidney was perfused only with uroguanylin or guanylin at the same dose $(0.5 \mu \mathrm{g} / \mathrm{ml})$. The doses of guanylin and uroguanylin employed in this study were based on previous reports by Fonteles and coworkers (16) that established a dose-response curve of guanylin and uroguanylin in the perfused rat kidney assay. Statistical analysis was carried out by the Fisher test (based on one-way ANOVA), and with the level of significance set at $\mathrm{P}<0.05$.

Pretreatment with ANP clearly promoted natriuresis, reflected as a reduction in $\% \mathrm{TNa}^{+}$ (Figure 1, panel A) and also caused an increase in diuresis (urinary flow; Figure 1, panel B) in guanylin-treated kidneys. ANP also increased Cosm (from $0.08 \pm 0.01$ to $0.412 \pm 0.071 \mathrm{ml} \mathrm{g}^{-1} \mathrm{~min}^{-1}, 120 \mathrm{~min}, \mathrm{P}<0.05$ ) in guanylin-treated kidneys. In contrast to these observations, ANP blocked the uroguanylin-induced natriuresis and increase in UF, as shown in Table 1. ANP also blocked the uroguanylin-induced increase in Cosm (from $0.20 \pm 0.01$ to $0.087 \pm 0.004 \mathrm{ml} \mathrm{g}^{-1}$ $\min ^{-1}, 120$ min, $\left.\mathrm{P}<0.05\right)$.

The results of Cosm promoted by pretreatment with ANP in both guanylin and uroguanylin-treated kidneys suggest that the interactions between the peptides occur at a nephron site away from distal tubules, since vasopressin was not added to the system at any time.

We should emphasize that neither ANP nor guanylin has any natriuretic effect at this dose (Figure 1). At these doses neither uroguanylin or guanylin caused any significant changes in perfusion pressure or in glomerular filtration rate, and ANP did not change this pattern (data not shown).

Thus the synergism between ANP +

Table 1 - Comparison of the natriuresis (reduction in fractional sodium transport $\left(\% \mathrm{TNa}^{+}\right)$) and diuresis (increase in urine flow (UF)) induced by uroguanylin (Urog), atrial natriuretic peptide (ANP), uroguanylin plus ANP (ANP + Urog) and control.

Data are reported as means $\pm \mathrm{SEM} . * \mathrm{P}<0.05$ (Fisher test, $\mathrm{N} \geq 9$ ). The previous introduction of ANP into the system blocked the uroguanylin-induced increase in UF and the decrease in $\% \mathrm{TNa}^{+}$(natriuretic effect).

\begin{tabular}{|c|c|c|c|c|c|}
\hline & & $30 \mathrm{~min}$ & $60 \mathrm{~min}$ & $90 \mathrm{~min}$ & $120 \mathrm{~min}$ \\
\hline UF & Control & $0.141 \pm 0.007$ & $0.153 \pm 0.008$ & $0.167 \pm 0.007$ & $0.158 \pm 0.007$ \\
\hline \multirow[t]{3}{*}{$\left(\mathrm{ml} \mathrm{g} \mathrm{g}^{-1} \mathrm{~min}^{-1}\right)$} & ANP & $0.130 \pm 0.025$ & $0.130 \pm 0.025$ & $0.150 \pm 0.025$ & $0.220 \pm 0.025$ \\
\hline & Urog & $0.120 \pm 0.010$ & $0.180 \pm 0.010^{*}$ & $0.200 \pm 0.010^{*}$ & $0.210 \pm 0.010^{*}$ \\
\hline & ANP + Urog & $0.138 \pm 0.012$ & $0.140 \pm 0.007$ & $0.132 \pm 0.008$ & $0.121 \pm 0.011$ \\
\hline \multirow[t]{4}{*}{$\% \mathrm{TNa}^{+}$} & Control & $80.51 \pm 0.85$ & $80.75 \pm 0.84$ & $79.95 \pm 0.96$ & $80.28 \pm 0.63$ \\
\hline & ANP & $81.16 \pm 1.93$ & $78.60 \pm 1.93$ & $81.20 \pm 1.93$ & $79.30 \pm 1.93$ \\
\hline & Urog & $78.06 \pm 0.70$ & $76.46 \pm 0.68^{*}$ & $74.82 \pm 1.53^{*}$ & $72.04 \pm 0.86^{*}$ \\
\hline & ANP + Urog & $81.16 \pm 0.60$ & $82.72 \pm 1.13$ & $84.02 \pm 1.42$ & $85.19 \pm 1.48$ \\
\hline
\end{tabular}


guanylin and the unexpected antagonism between ANP + uroguanylin suggest the existence of new receptors or new isoforms of GC-C mediating the renal actions of guanylins. Until now, there are no other receptors known to mediate any action of guanylins or STa, but other ligand sites have been recognized (17). GC-C has two kinetically distinct states with different affinity for ${ }^{125}$ I-labeled STa (18). "Cross-talking" between the guanylin/STa receptor and ANP receptor at the level of intracellular signal transduction is another explanation for these observations, since they share amino acid homology.

There are different mediators that regulate kidney salt and water excretion that may involve potential interactions between guanylin and uroguanylin, such as FNS (factor natriureticus similis), a peptide liberated from the hypoxic perfused rat kidney that causes natriuresis through an increase in
cGMP (19), and urodilatin, another natriuretic peptide that increases the level of cGMP within renal cells (20).

If our initial observation is confirmed after the survey of other interactions between guanylin, uroguanylin and the other mediators mentioned above, new experiments should be done in order to search for these new subtypes of receptors, using cDNA cloning and immunocytochemistry. Studies with guanylin/uroguanylin antagonists provide another good perspective for the future, since these compounds are not available at this time.

\section{Acknowledgments}

We thank Maria Silvia F. França and Domingos Barreto for their expert technical help and Luis Alberto M. Carvalho for computation assistance.

\section{References}

1. Schulz S, Chrisman TD \& Garbers DL (1992). Cloning and expression of guanylin - its existence in various mammalian tissues. Journal of Biological Chemistry, 267: 16019-16021.

2. Currie MG, Fok KF, Kato J, Moore RJ , Hamra FK, Duffin KL \& Smith CE (1992). Guanylin: an endogenous activator of intestinal guanylate cyclase. Proceedings of the National Academy of Sciences, USA, 89: 947-961.

3. Hamra FK, Forte LR, Eber SL, Pidhorodeckyj NV, Krause WJ, Freeman $\mathrm{RH}$, Chin DT, Duffin KL, Siegel NR \& Currie MG (1993). Uroguanylin: structure and activity of a second endogenous peptide that stimulates intestinal guanylate cyclase. Proceedings of the National Academy of Sciences, USA, 90: 10464 10468.

4. Forte LR \& Hamra FK (1996). Guanylin and uroguanylin: intestinal peptide hormones that regulate epithelial transport. News in Physiological Sciences, 11: 1724.

5. Greenberg RN, Hill M, Crytzer J, Krause WJ , Eber SL, Hamra FK \& Forte LR (1997). Comparison of effects of uroguanylin, guanylin and Escherichia coli heat-stable enterotoxin STa on mouse intestine and kidney: evidence that uroguanylin is an intestinal natriuretic hormone. J ournal of Investigative Medicine, 45: 5276-5282.

6. Forte LR \& Currie MG (1995). Guanylin: a peptide regulator of epithelial transport. FASEB J ournal, 9: 643-650.

7. Lima AAM, M onteiro HSA \& Fonteles MC (1992). The effects of Escherichia coli enterotoxin in renal sodium tubular transport. Pharmacology and Toxicology, 70: 163-167.

8. Fonteles MC, Monteiro HSA, Soares AM, Santos-Neto MS, Greenberg RN \& Lima AAM (1996). The lysine-1 analog of guanylin induces intestinal secretion and natriuresis in the isolated perfused kidney. Brazilian J ournal of Medical and Biological Research, 29: 267-271.

9. Sosa RE, Volpe M, Marion DN, Atlas SA, Laragh J H, Vaughan J r D \& Maack T (1986). Relationship between renal hemodynamic and natriuretic effects of atrial natriuretic factor. American J ournal of Physiology, 250: F520-F524.

10. Gaillard CA, Mizelle $H L, M$ ontani J $-P$, Brands MW, Hildebrand DA \& Hall JE (1990). Atrial natriuretic factor and blood pressure control: role of sodium and aldosterone. American J ournal of Physiology, 259: R973-R980.
11. Awazu M \& Ichikawa I (1993). Biological significance of atrial natriuretic peptide in the kidney. Nephron, 63: 1-14.

12. Fonteles MC, Cohen JJ, Black AJ \& Werthein SJ (1983). Support of kidney function by long-chain fatty acids derived from renal tissue. American J ournal of Physiology, 244: F235-F246.

13. Wasler M, Davidson DG \& Orloff J (1955) The renal clearance of alkali-stable inulin. J ournal of Clinical Investigation, 34: 15201523.

14. Martinez-Maldonado $M \&$ Opava-Stitzer $S$ (1978). Free water clearance curves during saline, manitol, glucose and urea diuresis in the rat. J ournal of Physiology, 280: 487-497.

15. Wiegand RC, Kato J \& Currie MG (1992). Rat guanylin cDNA: Characterization of the precursor of an endogenous activator of intestinal guanylate-cyclase. Biochemical and Biophysical Research Communications, 185: 812-817.

16. Fonteles MC, Greenberg RN, Monteiro HSA, Currie MG \& Forte LR (1998). Natriuretic and kaliuretic activities of guanylin and uroguanylin in the isolated perfused rat kidney. American J ournal of Physiology, 275 (Renal, Fluid and Electrolyte Physiology, 44): F191-F197. 
17. Mann EA, Cohen $M B \&$ Gianella RA (1993). Comparison of receptors for Escherichia coli heat-stable enterotoxin: novel receptor present in IEC-6 cells. American J ournal of Physiology, 264: G172-G178.

18. Crane MR, Hughes M, O'Hanley PD \& Waldman SA (1992). Identification of two affinity states of low affinity receptors for Escherichia coli heat-stable enterotoxin: correlation of occupation of lower affinity state with guanylate cyclase activation. Molecular Pharmacology, 41: 1073-1080.

19. Fonteles MC, Villar-Pallasi C, Fang G, Lamer J \& Guerrant RL (1993). Partial characterization of an ANF/urodilatin-like substance from perfused rabbit kidney under hypoxia. Brazilian J ournal of Medical and Biological Research, 26: 75-79.

20. Kirchoff $K$, Bub A, Marxen $P \&$ Frossman W-G (1994). Urodilatin inhibits sodium reabsorption in the isolated perfused rat kidney. Experimental Nephrology, 2: 231237. 